\title{
DARI ANARKI KE HIRARKI: EKSPOSISI GAGASAN THOMAS HOBBES SEBAGAI RUJUKAN TEORI REALISME
}

\author{
${ }^{1}$ Stenly Djatah, ${ }^{2}$ Carmely Eucharisty \\ ${ }^{1}$ Hubungan Internasional, Fakultas Ilmu Sosial dan Ilmu Politik \\ Universitas Jenderal Achmad Yani \\ Stenly.djatah@lecture.unjani.ac.id \\ ${ }^{2}$ European Legal Studies, Faculty of Law and Administration, Adam \\ Mickiewicz University, Poznan Poland \\ careuc@st.amu.edu.pl
}

\begin{abstract}
In International Relation theory discourse, Realism Theory has some typical characteristics that differentiate it from other theories. The typical characteristics can be indicated by the ideas of Anarchy and Conflict. The two ideas in Realism theory refers to Thomas Hobbes' Political Philosophy on the State of Nature. Considering that the two ideas are only two of the entire ideas of Thomas Hobbes' Political Philosophy, the State of Anarchy and Conflict in Realism theory needs to be completed with other ideas. The writing has been made to show the function of ratio as a reason to seek peace in a hierarchical relation through Leviathan's power. Therefore, it can be seen that Thomas Hobbes discusses not only about the state of anarchy but also the fact of hierarchical system urgency to avoid conflict. Key Words: Anarchy, Hierarchy, Peace, Conflict, War, Realism
\end{abstract}

\section{PENDAHULUAN}

Tulisan ini adalah argumentasi penulis untuk membuktikan bahwa gagasan Anarki bukan gagasan terpisah dari gagasan Hirarki dalam pemikiran Politik Thomas Hobbes. Gagasan Hirarki adalah bentuk evolusi akhir dari Keadaan Alamiah yang menjelaskan hubungan subyek baik hubungan antar individu dengan Negara juga Negara dengan Negara demi mengelak perang. Mengapa perlu ditunjukkan evolusi keadaan Anarki ke Hirarki? Keperluan argumentasi ini dimaksudkan sebagai jalan 
memahami kontribusi pemikiran Thomas Hobbes dalam teori Realisme (Chong, 2005).

Gagasan Thomas Hobbes oleh teori Realisme dalam studi Hubungan Internasional dianggap sebagai rujukan valid bagi menegakkan ide Anarki (Pedro, 2018). Artinya, Keadaan tanpa kekuasaan melampaui kekuasaan setara yang dimiliki oleh subyek Negara. Keadaan ini dianggap merujuk pada Keadaan Alamiah dalam teori Thomas Hobbes. Dalam keadaan alamiah, setiap individu memiliki kesetaraan dalam hal kebebasan, kekuasaan, keinginan, pembelaan diri dan hak menghukum. Karakteristik Keadaan Alamiah ini diadopsi ke dalam teori Realisme melalui terminologi Anarki. Oleh ide ini, karakteristik sistem internasional dibangun. Sebuah negara bukan subjek subordinan dari Negara yang lain. Artinya tidak ada hubungan hirarkis dalam sistem internasional (Stephen McGlinchey, 2017). Tentu benar, jika sistem internasional oleh teori realism dipahami berdasarkan Keadaan Alamiah seperti di atas maka hubungan antar subjek dalam sistem internasional bukan hirarkis. Disisi yang lain oleh Keadaan Alamiah, masing-masing subjek rentan konflik. Kekuasaan dan kebebasan alamiah masing-masing subjek menjadi penyebabnya. Ide inipun menjadi gagasan penting dalam teori Realisme Klasik. Bahwa Negara adalah rentan perang.

Rujukan teori Realisme terhadap Thomas Hobbes berkait dengan gagasan anarki dan konflik memerlukan gagasan yang sinambung. Mengadopsi Hobbes terbatas pada gagasan anarki dan konflik seperti di atas tentu hanyalah sebagian kecil dari gagasan pemikiran Politik Thomas Hobbes. Pembacaan atas Thomas Hobbes menjadi pincang jika memisahkan gagasan fungsi rasio sebagai sumber perdamaian yang oleh Thomas Hobbes justru harus dicapai melalui hubungan hirarkis yang dimiliki subyek. Oleh sistem hirarkis, Hobbes memandang konflik dapat dihindari meskipun harus diakui diperlukan kekuasaan Leviathan (kekuasaan pedang) untuk menciptakan perdamain dan mengelak perang. 
Untuk keperluan argumentasi dimaksud, berikut penulis mengemukakan gagasan-gagasan Hobbes dengan maksud menunjukkan evolusi gagasan dari Keadaan Alamiah yang menjadi rujukan Realisme kepada keadaan Hirarki sebagai jalan menciptakan perdamaian.

\section{KEADAAN ALAMIAH (STATE OF NATURE)}

Gagasan filsafat politik Hobbes, dapat ditemukan secara utuh dalam karyanya, Leviathan (1651) dan De Cive (1642). De Corpore Politico (1656). Dalam karya-karyanya, Hobbes membincangkan tiga gagasan basisnya, yaitu Keadaan Alamiah (State of Nature), Sosial Kontrak (Social Contract) dan Kekuasaan Negara (Power State). Tiga gagasan basis ini merupakan satu rangkaian gagasan yang tidak dapat dipisahkan. Baik Keadaan Alamiah, Sosial Kontrak dan Kekuasaan Negara, bersumber dari satu postulat yang sama, yaitu bahwa secara alamiah, manusia memiliki kekuasaan (Hobbes, 1642). Kekuasan Alamiah manusia ini yang akhirnya menjadi sentral pembicaraan tiga rangkaian gagasan diatas. Berdasarkan pemahaman tersebut, dalam pandangan Hobbes, manusia adalah subyek penggagas lahirnya negara dan pembicaraan tentang kekuasaan politik.

Keadaan Alamiah manusia oleh Hobbes ditempatkan sebagai bagian pertama dalam Leviathan, De Cive dan De Corpore. Hal ini menjadi petunjuk bahwa Hobbes, ingin menjadikan gagasan Keadaan Alamiah Manusia sebagai sumber gagasan filsafat politiknya. Pembicaraan tentang Commonwealth dalam bagian kedua, Commonwealth Kristen dalam bagian ketiga dan yang terakhir, bagian keempat yaitu: Kerajaan Kegelapan, harus diinterpretasi berdasarkan postulat Hobbes tentang Keadaan Alamiah Manusia.

Sebelum membicarakan gagasan-gagasan Hobbes tentang sosial kontrak dan Kekuasaan Negara, saya akan menjelaskan apa yang saya sebut sebagai postulat Hobbes tentang Keadaan Alamiah manusia. Ada lima gagasan basis yang digunakan oleh Hobbes dalam postulatnya 
tentang Keadaan Alamiah manusia. Lima gagasan itu ialah: pertama, bahwa setiap individu memiliki Kekuasaan Alamiah (Natural Power) untuk memenuhi keinginannya (desire). Kedua, tiap-tiap individu secara alamiah, adalah setara. Ketiga, keadaan perang (Condition of Warre), Keempat, Hak Alamiah (Jus Naturalis) dan Kebebasan (Liberty) dan yang Kelima, Hukum Alam (Lex Naturalis) (Hobbes, 1947)

\section{Kekuasaan Alamiah (Natural Power).}

Kekuasaan alamiah adalah gagasan basis pertama yang digunakan untuk menjelaskan peranan sentral individu dalam gagasan filsafat politik Hobbes. Dari gagasan Kekuasaan Alamiah ini, Hobbes melahirkan idea tentang Kesetaraan, Hak, Kebebasan, Kekuasaan, Hukum dan Negara yang kemudian menjadi satu mata rantai dalam sistem filsafat politiknya. Tentang esensi kekuasaan manusia, Hobbes (Hobbes: 1947) mengatakan:

THE POWER of Man, (to take it universally), is his present means, to obtain some future apparent Good. And is either Original, or Instrumental. Natural Power is the eminence of the Faculties of Body, or Mind: as extraordinary Strength. Forme, Prudence, Arts, Eloquence, Liberty, Nobility. Instrumental are those Powers, which acquired by these, or fortune, are means and Instruments to acquire more: as Riches, Reputation, Friends and the secret working of God, which men call Good Luck.

Secara hakiki, Hobbes mengakui bahawa manusia memiliki Kekuasaan. Kekuasaan itu disebut sebut sebagai Kekuasaan original dan instrumental. Kekuasaan Original, artinya kekuasaan yang bersumber dari kemampuan fisikal (body) dan akal (mind). Sedangkan kekuasaan Instrumental artinya kekuasaan yang diperoleh karena status sosial atau mukjizat dari Tuhan. Hooker menyebut Kekayaan, Reputasi, Kemujuran sebagai instrumen seseorang mendapatkan kekuasaan Instrumental.

Kekuasaan original dan instrumental yang dipadukan Hobbes sebagai citra individu-individu politik menjadi salah satu basis gagasan filsafat Politiknya. Hobbes dengan cara ini menjadikan individu, bukan 
institusi Negara sebagai penyebab lahirnya gagasan Hukum dan Kekuasaan Negara. Tanpa individu-individu, tidak ada gagasan Hukum dan Kekuasaan Negara. Ada dua implikasi yang dapat lahir dari gagasan Kekuasaan Original dan Instrumental yang dicetuskan Hobbes, yaitu: pertama, bahwa setiap individu oleh karena kemampuan fisik (body) dan akal (mind) adalah setara (equal) (Hobbes, 1947). Namun pada bagian yang lain, gagasan sumber kekuasaan manusia melalui instrumen dapat melahirkan citra individu-individu yang tidak setara (unequal), karena secara hakiki, setiap individu memiliki status kekayaan dan reputasi yang berbeda. Gagasan instrumen itu melahirkan diskriminasi. Kaum elit, karena status sosialnya akhirnya dapat memiliki dominasi kekuasaan yang lebih besar dibandingkan dengan individu lain.

Hobbes memahami fungsi kekuasaan alamiah (original dan instrumental) sebagai kekuasaan individu-individu untuk mencapai keinginan (desire) Namun demikian fungsi ini menciptakan iklim beresiko konflik (Bibio, 1993). Kondisi individu yang tidak setara kerana gagasan kekuasaan instrumental, menjadikan kesempatan meraih kebahagiaan dimonopoli kaum elit yang menguasai sumber-sumber kekayaan.

\section{Kesetaraan Alamiah (Natural Equality)}

Gagasan Kesetaraan (Equality), oleh Hobbes dipahami berdasarkan kondisi aktual manusia. Fakta adanya kemampuan fisik dan Akal merupakan alasan mengapa setiap individu oleh Hobbes dipandang setara. Kesetaraan ini adalah Alamiah (Hobbes, 1947). Artinya ia bukan hasil dari kesepakatan instrumen sosial atau politik. Keadaan setara tersebut dipahami sebagai kesetaraan potensi fisik dan akal manusia. Meskipun Hobbes menggagas Kesetaraan (equality) namun Kesetaraan ini oleh Hobbes tetap diinterpretasi secara negatif. Artinya, Kesetaraan tidak serta merta menjadikan individu-individu dapat saling menghormati satu dengan yang lain. Kesetaraan dapat menjadi sumber pertikaian. Oleh karena Kesetaraan, setiap individu memiliki hak dan kekuasaan yang 
sama menguasai apa yang ingin dikuasainya. Dapat terjadi, bahwa seorang individu melakukan kekerasan atau memusnahkan individu yang lain demi mendapatkan apa yang diinginkan. Individu yang lain pun dapat melakukan kekerasan yang sama untuk melindungi dirinya. Kesetaraan ini ternyata menimbulkan permusuhan diantara manusia (Hobbes, 1947).

Gagasan Kesetaraan Alamiah Hobbes menyisakan persoalan, karena berantitesis dengan gagasan Kekuasaan Instrumental yang juga disebut sebagai Kekuasaan Alamiah. Individu dipandang setara, namun oleh karena kekuasaan instrumental menjadi tidak setara. Antitesis ini dapat dipandang sebagai kecacatan gagasan Hobbes tentang Kesetaraan.

\section{Keadaan Perang (Condition of War)}

Dalam gagasan filsafat politik Hobbes, kecenderungan konflik dianggap sebagai hal yang alamiah. (Hobbes, 1947). Kecenderungan ini digunakan Hobbes menjadi dasar bagi teorinya tentang Keadaan Alamiah (State of Nature) sebagai Keadaan Perang (Condition of War) (Kavka, 1983). Keadaan Perang yang dimaksud oleh Hobbes adalah satu keadaan dimana setiap orang menjadi musuh bagi orang lain, tidak ada hukum yang disepakati bersama untuk melindungi kehidupan individu-individu dalam masyarakat (Kavka, 1983). Hobbes memberi penjelasan mengapa kondisi perang dapat terjadi, demikian:

So that in the nature of man, we find three principles that cause quarrel. First, Competition, Secondly, Diffidence, Thirdly, Glory. The first maketh men invade for Gain, the second, for safety; and the third for reputation. The first use violence, to make them Masters of other mens persons, wives, children and cattle, the second to defend them; the third for trifles.

Pernyataan Hobbes diatas menunjukkan bahwa secara alamiah, manusia memang memiliki kecenderungan mencari keuntungan pribadi. Untuk mendapatkan keuntungan tersebut, individu-individu menggunakan kekerasan terhadap individu yang lain. Boleh dikatakan bahwa Kondisi Perang adalah kondisi bawaan (inherent) yang secara 
natural ada dalam diri manusia bersama dengan hadirnya keinginan (desire).

Leo Strauss mengukuhkan gagasan Hobbes tentang fakta adanya keinginan menguasai dalam diri manusia melalui dua postulat. Yang pertama ia sebut dengan natural appetite (Strauss, 1963) mengatakan demikian, Hobbes summed up his theory of human nature as it underlies his political philosophy in two most certain postulates of human nature. The first postulate is that of 'natural appetite'.

Natural appetite yang dimaksud oleh Strauss adalah hasrat alamiah yang dimiliki hewan secara umum termasuk di dalamnya manusia (Kavka, 1963). Meskipun demikian Strauss membedakan human natural appetite dan animal natural appetite. Human Natural appetite adalah hasrat manusia yang spontan dan tidak terbatas. Artinya, hasrat tersebut dapat digunakan untuk memenuhi hasrat masa kini dan juga masa depan untuk waktu yang tidak terbatas. Hal ini berbeda dari Animal Natural appetite yang terbatas pada objek (Straus, 1963). Artinya hewan hanya memiliki keinginan untuk memenuhi keperluannya pada saat adanya keinginan itu, dan terbatas pada objek tertentu. Misalnya, mencari mangsa untuk memenuhi rasa lapar. Kedua natural appetite ini dapat dibedakan karena manusia memiliki akal (Straus, 1983). Postulat Strauss tentang Natural Appetite sangat jelas memberi dukungan terhadap Condition of War yang digagas Hobbes. Menurut Strauss, perbincangan tentang keadaan alamiah manusia tidak dapat pisahkan dari proposisi bahwa manusia secara alamiah memiliki keinginan yang besar untuk menguasai. Ini merupakan ekspresi paling sempurna dari human natural appetite (Straus, 1969). Implikasinya, keinginan untuk menguasai harus dipandang sebagai karakter dasar manusia. Dari sinilah Keadaan Perang dilahirkan. 
Postulat kedua yang digunakan Strauss menjelaskan keadaan alamiah manusia dalam gagasan filsafat politik Hobbes adalah Natural Reason. Tentang hal ini, (Strauss, 1969) mengatakan bahwa:

In accordance with naturalistic reasoning this postulat is reduced to the principle of the self-preservation: since the preservation of life is the condition sine qua non for the satisfaction of any appetite, it is the primary good. As a logical conclusion of this thought, Hobbes attempts to deduce natural right, natural law, and all the virtues from the principle of self-preservation.

Gagasan Strauss diatas menunjukkan, secara natural akal manusia memproduksi gagasan, bahwa perlindungan diri dipahami sebagai kebaikan utama (primary good). Karena itu manusia secara natural selalu berjuang melindungi dirinya sendiri dari ancaman orang lain. Perlindungan diri ini merupakan produk dari akal (affirmed by reason) semata-mata. Antitesis dari kebaikan utama (primary good) yang dinyatakan melalui akal (affirmed by reason) adalah kejahatan utama (primary evil) yang dikenali melalui perasaan (confirmed by passion) (Strauss, 1969). Yang dimaksudkan oleh Strauss adalah, bahwa secara alamiah, akal (reason) dan perasaan (passion) merupakan dua potensi yang dimiliki manusia mendapatkan perlindungan diri dan menghindari penderitaan.

Jika postulat pertama Strauss berimplikasi justifikasi terhadap condition of war berdasarkan keinginan alamiah (natural appetite) menghindari penderitaan, postulat kedua merupakan justifikasi terhadap condition of war berdasarkan akal alamiah (Natural Reason). Dua postulat Strauss ini bukan hanya menjadi basis interpretasinya terhadap gagasan Hobbes tentang condition of war tetapi juga terhadap keseluruhan gagasan filsafat politik Hobbes.

Postulat Strauss diatas, sejalan dengan interpretasi Gregory S. Kavka tentang Keadaan Alamiah manusia sebagai Keadaan Perang (Condition of War). Kavka mengatakan bahawa, So war of all against all is 
a state in which each knows that every other is willing to fight him, not one in which is constantly fighting (Kavka:1983). Pernyataan Kavka ini menegaskan bentuk sebenarnya dari Keadaan Perang yang dimaksud Hobbes. Keadaan Perang (Condition of War) adalah Keinginan konflik alamiah namun tidak terjadi secara terus menerus. Baik Strauss dan Kavka memandang bahwa Keadaan Perang semuanya bersumber dari Keinginan alamiah, yang secara esensi cenderung melahirkan konflik antara sesama manusia. Pernyataan Strauss dan Kavka mengindikasikan bahwa, gagasan Hobbes tentang Keadaan Perang bukan kondisi perang yang secara historis terjadi dalam Keadaan Alamiah Manusia. Keadaan Perang boleh disebut sebagai watak buruk manusia yang ingin menguasai sesamanya. Strauss dan Kavka, menggunakan argumentasi psikologis untuk menjelaskan gagasan Hobbes tentang Keadaan Perang. Hal ini juga sejalan dengan pendapat (Jean Hampton, 1986) bahwa keadaan perang menunjuk pada kekacauan moral.

\section{Hak Alamiah (Jus Naturale)}

(Hobbes, 1947) menjelaskan Hak Alamiah (Jus Naturale) dan Kebebasan demikian:

The RIGHT OF NATURE which Writers commonly call Jus Naturale is the Liberty each man hath, to use his own power, as he will himself, for the preservation of his own Nature, that is to say of his own Life and consequently, of doing anything, which in his own Judgement, and Reason, he shall conceive to be the aptest means thereunto. By LIBERTY is understood, according to the proper signification of the word, the absence of of external Impediments: which impediments may oft take away part a man's power to do what he would; but can not hinder him from using the power left him, according as his judgement, and reason shall dictate to him.

Dalam kutipan sebelumnya, Hak Alamiah (Jus Naturalis) oleh Hobbes dikaitkan dengan Kekuasaan, Keinginan untuk melindungi diri dan Pertimbangan Akal Sehat (Hobbes, 1994).Artinya, Hak Alamiah tiaptiap individu untuk memenuhi apa saja yang diinginkan terutama untuk 
melindungi dirinya dengan cara apapun (Hobbes, 1651) dilakukan berdasarkan Kekuasaan Alamiah (Natural Power), Kebebasan dan Pertimbangan Akal Sehat yang ia miliki (Hobbes, 1651).

Bagi Hobbes Hak Alamiah dan Kebebasan merupakan bukti adanya otonomi yang sempurna. Setiap individu memilikinya. Seorang individu oleh karena Hak Alamiah dan Kebebasan, dapat melakukan semua yang dianggap menguntungkan dirinya (Hobbes, 1651). Dengan demikian, dalam pandangan Hobbes, secara hakiki, tiap-tiap individu mempunyai hak untuk memiliki apa saja. Mengapa? Hobbes mengatakan bahwa, Natura dedit omnia, omnibus, alam semesta telah memberi semua hal kepada semua manusia (Hobbes, 1994). Implikasinya, segala hal yang disediakan oleh alam adalah untuk keperluan semua manusia. Tiap-tiap individu memiliki Hak Alamiah untuk memanfaatkannya.

Meskipun demikian, Hobbes memandang bahwa secara alamiah, tindakan tiap-tiap individu dikontrol oleh pertimbangan Akal Sehat. Artinya, semua tindakan yang dilakukan oleh individu, lahir dari satu proses yang rasional. Berangkat dari pertimbangan rasional itu, secara rasional juga harus dikatakan bahwa seorang individu semestinya bukan hanya memiliki Hak Alamiah untuk memenuhi keinginannya tetapi juga memiliki Hak Alamiah untuk membela diri dari ancaman individu lain yang mengekspresikan Hak Alamiahnya secara rasional. Baik Hak untuk mendapatkan perlindungan diri dan Hak untuk membela diri, keduaduanya harus dipandang sebagai hal yang Alamiah.

Susanne Sreedhar (2008) memberi interpretasi gagasan Hak Alamiah Hobbes sebagai inalienability. Jika setiap individu secara alamiah memiliki Hak Alamiah (Jus Naturale) yang sifatnya inalienability untuk mendapatkan apa saja yang diinginkan dengan cara apapun, termasuk cara perang (War), ini berarti bahawa setiap individu secara alamiah juga memiliki Right of Self Defense yang sifatnya inalienability sebagai cara untuk melindungi diri. 
Pendapat Sreedhar ini sejalan dengan maksud Hobbes tentang fakta adanya Keinginan dalam Keadaan Alamiah manusia (Natural appetite) dan Akal Alamiah (Natural Reason). Penggunaan kata "inalienability" oleh Sreedhar untuk menjelaskan gagasan Hobbes tentang Hak Alamiah, memperkokoh hubungan gagasan antara Hak Alamiah dan Keinginan Alamiah. Jika, seorang individu memiliki Keinginan Alamiah maka ia memiliki Hak Alamiah untuk memenuhi apa yang ia inginkan. Hak Alamiah tentunya ada dalam diri seorang individu bersama-sama dengan Keinginan Alamiah. Jika seorang individu memiliki Hak secara Alamiah maka, Keinginan seorang individu pun tentunya dimiliki secara Alamiah juga. Jika gagasan Hobbes tentang Hak Alamiah oleh Sreedhar disebut sebagai inalienability tentunya Keinginan Alamiah juga adalah inalienability. Aspek inalienability gagasan Hobbes tentang Hak Alamiah nampak juga dalam penjelasan David P Gauthier (1969) melalui formula logika seperti berikut:

'A has the right to do X' = 'A may do X'

'A has the natural right to do $\mathrm{X}=\mathrm{A}$ may initially do $\mathrm{X}$

'A has the natural right to do $\mathrm{X}$ ' = A may initially do $\mathrm{X}$ for the preservation of his own nature'

A may do $\mathrm{X}$ ' = 'A doing $\mathrm{X}$ is in accordance with (right) reason' 'A has the natural right to do $\mathrm{X}^{\prime}=\mathrm{A}$ doing $\mathrm{X}$ ' is in accordance with (right)

reason. And a has the natural rights to do $\mathrm{X}^{\prime}=\mathrm{A}$ doing $\mathrm{X}$ initially in accordance with (right) reason.

Formula Gauthier tentang logika Hobbes dalam Leviathan, menghubungkan tiga gagasan yaitu Natural Right, Reason dan Self preservation. Gauthier membatasi penjelasanya tentang Hak Alamiah berdasarkan hubungan rasional antara Hak Alamiah, Akal dan Perlindungan Diri. Hubungan rasional yang diungkap Gauthier melalui formula logikanya diatas yaitu: bahwa dalam Leviathan, Jika seorang individu memiliki Hak Alamiah untuk melakukan X maka, individu yang bersangkutan akan melakukan menurut pertimbangan akal sehat. 
Memang dalam Keadaan Alamiah, Hobbes menghubungkan antara Hak Alamiah dan fungsi akal sehat untuk melakukan satu tindakan (Hobbes, 1947). Namun demikian hubungan yang digambarkan oleh Gauthier, harus dikatakan hanya sebagian dari gagasan Hobbes tentang manusia dalam Keadaan Alamiah karena disamping memandang individu dalam Keadaan Alamiah memiliki Hak Alamiah dan Akal Alamiah, Hobbes juga memahami adanya Keinginan dan Kekuasaan Alamiah yang dimiliki tiap-tiap individu (Hobbes, 1947).

Implikasi logika Hobbes yang digagas Gauthier adalah, Hak Alamiah dapat dipenuhi meskipun tanpa Kekuasaan Alamiah. Pertimbangan Akal Alamiah dianggap cukup untuk memenuhi apa yang menjadi hak-hak alamiah seorang individu. Hal ini tentunya, merupakan sebuah kekeliruan interpretasi terhadap gagasan Hobbes. Pengabaian, keterlibatan Keinginan Alamiah dan Kekuasaan Alamiah, justru mereduksi potensi kekuasaan politik seorang individu yang sejak mulanya menjadi gagasan basis Hobbes. Karena itu, gagasan tentang Hak Alamiah, sepatutnya dibicarakan dengan menghubungkan antara Hak Alamiah, Akal Alamiah, Keinginan Alamiah dan Kekuasaan Alamiah yang dimiliki oleh tiap-tiap individu. Formula logika Hobbes tentang Hak Alamiah yang digagas oleh Gauthier harus diperluas dengan menambahkan hubungan Keinginan Alamiah dan Kekuasaan Alamiah ke dalam logika Hak Alamiah. Untuk hal ini perluasan harus dilakukan. Hak Alamiah perlu berdasarkan tiga postulat yaitu:

1. Tiap-tiap individu memiliki Hak Alamiah (Jus Naturale)

2. Tiap-tiap individu memiliki Keinginan dan Akal Alamiah (Natural Reason and Desire)

3. Tiap-tiap individu memiliki Kekuasaan Alamiah ( Natural Power) Karena ketiga potensi dalam postulat di atas dimiliki oleh tiap-tiap individu pada saat yang sama maka harus dianggap tidak ada hubungan sebab akibat diantara ketiga postulat itu. Artinya, Hak Alamiah bukan disebabkan oleh Keinginan Alamiah dan Kekuasaan Alamiah. Ketiga 
potensi dalam postulat di atas bersumber dari satu esensi yaitu esensi Alamiah. Justru karena ada esensi alamiah maka ketiga postulat dapat disebut sebagai hal yang alamiah. Dengan demikian tiga potensi dalam postulat di atas boleh dipastikan sebagai implikasi dari esensi Alamiah itu. Hal ini dapat digambarkan sebagai berikut:

$$
\text { ) ada Hak Alamiah (Jus Naturale) }
$$

Jika ada State of Nature) ada Akal dan Keinginan Alamiah (Natural Reason and Desire)

$$
\text { ) Kekuasaan Alamiah (Natural Power) }
$$

Jika Keadaan Alamiah kita sebut sebagai KA, maka: Hak Alamiah kita sebut sebagai KA-p, Akal Keinginan dan Alamiah: KA-q, Kekuasaan Alamiah: KA-r. Kerana tujuan yang ingin dicapai oleh setiap individu dalam Keadaan Alamiah adalah Perlindungan Diri (self preservation) maka, Perlindungan Diri ini kita sebut sebagai KA-s

Rumusan ini dapat ditulis demikian:

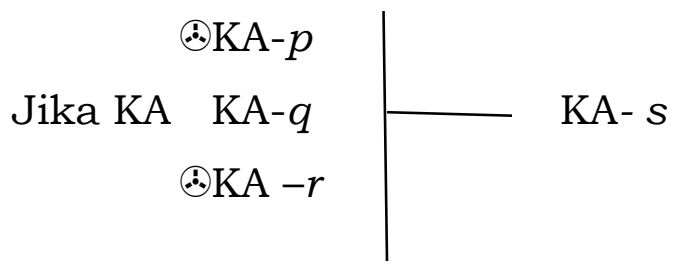

Beberapa ekuivalensi yang dapat muncul adalah:

- Jika X memiliki (KA- $p, \mathrm{KA}-q$ dan KA- $r) \odot \mathrm{X}$ mendapat KA-s

- Jika X memiliki (KA- $p, \mathrm{KA}-q$ dan KA-r) $\odot \mathrm{X}$ mendapatkan KA-s berdasarkan pertimbangan KA- $q 1$

- Jika X memiliki (KA- $p, \mathrm{KA}-q$ dan $\mathrm{KA}-r) \odot \mathrm{X}$ mendapatkan KA-s kerana KA- $p 1$.

- Jika X memiliki (KA- $p, \mathrm{KA}-q$ dan KA-r) $\odot \mathrm{X}$ mendapatkan KA-s Kerana KA-r

\footnotetext{
$\square$ : Jika X memiliki (KA-p, KAq dan KA-r X mendapatkan KA-s berdasarkan pertimbangan KA-q1 dan inherensi KA-p1 dan KA r1.
} 
Ekuivalensi ini tentunya memberi dukungan terhadap dua hal: pertama, fungsi Hak Alamiah, Kekuasaan Alamiah, Akal, Keinginan Alamiah seorang individu untuk mendapatkan self-preservation. Perlindungan diri ini tentunya hanya akan didapat jika seorang individu memiliki Hak Alamiah (p), Akal-Keinginan Alamiah (q) dan Kekuasaan Alamiah ( $r$. Ketiadaan satu dari fungsi diatas, menunjukkan bahwa tiada jaminan seorang individu dapat melindungi dirinya (s). Kedua. Dukungan terhadap karakteristik absolut (inalienability) daripada ketiga tiga fungsi $p$, $q$ dan $r$. Melalui ekuivalensi diatas dibuktikan bahwa $p, q$ dan $r$ adalah $\mathrm{KA}$, Artinya $\mathrm{p}$,q, dan $\mathrm{r}$ memiliki satu esensi, yaitu: esensi $\mathrm{KA}=$ Alamiah dan tentunya absolut (inalienability).

Karakteristik inalienability dari ketiga-tiga unsur $(p, q$, dan $r)$ dalam ekuivalensi diatas bukan hanya dapat menjelaskan gagasan Hobbes tentang hubungan rasional antara $p, q, r$ dan $s$ dalam keadaan Alamiah, tetapi juga membawa implikasi terhadap interpretasi fungsi $p, q r$ dan $s$ dalam doktrin Sosial Kontrak dan sumber Kekuasaan Negara. Hal ini dapat dipastikan benar kerana karakteristik alamiah dari $p, q, r$ dan $s$ secara esensial tidak akan berubah. Individu (X) yang mengandung unsur KA-p, q, r, dan s dalam Doktrin Keadaan Alamiah juga adalah inidvidu yang sama yang dibicarakan dalam Doktrin Sosial Kontrak dan sumber Kekuasaan Negara.

\section{Hukum Alamiah (Lex Naturale)}

Hobbes (1947) menjelaskan Hukum Alamiah seperti berikut:

A LAW OF NATURE (Lex Naturalis) is a Precept or general Rule, found out by Reason, by which a man is forbidden to do, that, which is destructive of his life, or taketh away the means of preserving the same; and to omit, that by which thinketh it may be best preserved.

Bagi Hobbes, Hukum Alamiah adalah hukum yang bersumber dari

Akal budi yang daripadanya individu dapat memutuskan sesuatu yang baik bagi dirinya sendiri. Hukum Alam yang disebut sebagai Hukum Akal 
budi ini, dalam tiga karya Hobbes, The Elements of Law Human Nature, De Cive dan Leviathan, tidak dihubungkan dengan hukum alam yang berlaku dalam kosmik karena Hobbes membatasi pengertian Hukum Alam, sebagai keterlibatan akal dalam proses mendapatkan self preservation. Jika ada akal maka ada self preservation (Kinch, 2002).

Dalam Leviathan, Hobbes mengklasifikasikan Hukum Alamiah ke dalam tiga bentuk, iaitu: General Rule, First (Fundamental) Law of Nature dan Second Law of Nature. Tiga klasifikasi diatas dijelaskan Hobbes (1947) demikian:

General rule of Reason, that every man ought to endeavor Peace, as far as he has hope of obtaining it; and when he cannot obtain it, that he may seek and use, all helps, and advantages of War. The first branch of which Rule contained the first, and Fundamental Law of Nature, which is to seek Peace, and follow it. The Second, the sum of the Right of Nature; which is, By all means we can, to defend ourselves. From this Fundamental Law of Nature, by which men are commanded to endeavor Peace, is derived this second Law; That a man be willing, when others are so too, as farre-forth, as for Peace and defence of himself he shall think it necessary, to lay down this right to all things; and be contented with so much liberty against other men. As he would allow other men against himself.

Hubungan ketiga bentuk hukum ini tidak linear tetapi hirarki. Artinya ada hukum tertinggi dan hukum yang menjadi subordinasinya Hal ini dapat digambarkan sebagai berikut:

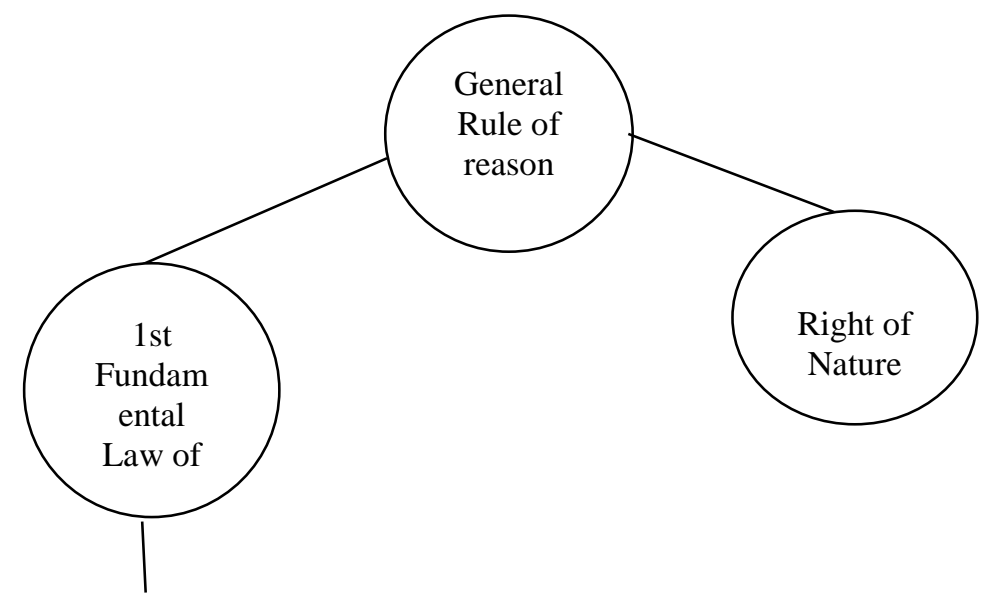


Dalam gagasan Hobbes, manusia dibicarakan sebagai individu yang memiliki Hak, namun demikian, akal akan melahirkan aturan agar dapat mengawasi Hak Alamiah yang secara esensi unlimited. General Rule of Reason itu dapat disebut sebagai hukum tertinggi dengan karakteristik unlimited. Ia menjadi unlimited karena bagi Hobbes tidak ada hukum yang lebih tinggi dari hukum akal. General Rule of Reason mengandung dua pengertian yaitu: pertama bahwa tiap- tiap individu berjuang mengupayakan suasana damai. Hal ini oleh Hobbes disebut sebagai first Fundamental Law of Nature. Kedua, jika dengan cara itu suasana damai tidak didapat, maka cara perang (war) dapat digunakan. Penggunaan hak mendapatkan self preservation melalui cara perang, oleh Hobbes disebut sebagai bentuk dari Hak Alamiah (Right of Nature).

Dari first Fundamental Law of Nature, Hobbes membuka jalan bagi gagasan kompromi hak antara individu-individu untuk tujuan perdamaian (Jaede, 2018). Gagasan kompromi hak itu adalah bahwa demi mengelakan konflik atau perang, seorang individu dapat menyerahkan semua hak-hak yang ia miliki jika individu yang lain juga mau menyerahkan hak-hak yang sama, dengan konsekuensi setiap individu tidak memiliki kebebasan dan hak untuk membela diri. Ini oleh Hobbes disebut sebagai second Law of Nature. Bagi Hobbes kompromi ini sebagai jalan yang harus ditempuh, karena sepanjang individu masih memiliki semua hak - hak alamiahnya, maka semua individu akan terus berada dalam keadaan perang (Hobbes, 1947). Namun harus diakui bahwa gagasan Hobbes tentang penyerahan semua hak - hak alamiah individu dalam second Law of Nature melahirkan persoalan. Gagasan penyerahan hak itu berantitesis dengan karakteristik permanen dan inalienability dari Hak Alamiah.

Gagasan Hobbes tentang Hukum Alam di atas melahirkan dua gagasan yang saling berantitesis tentang dasar pertimbangan Hobbes 
yang dengan sengaja mengubah hak-hak alamiah (Jus naturalis) yang permanen itu menjadi sesuatu yang dapat ditiadakan oleh hukum akal akal. Persoalan ini harus diterokai dengan menemukan korelasi gagasan Hukum Alamiah dengan gagasan hukum yang lain dalam karya-karya Hobbes. Hal ini dimaksudkan untuk melihat apakah gagasan Hukum Alamiah itu dijelaskan dalam karya Hobbes yang lain. Jika ada, maka, sepatutnya jawaban terhadap pertanyaan diatas diturunkan melalui semua gagasan Hobbes tentang Hukum Alamiah.

Memang Hobbes tidak menulis gagasan Hukum Alam (Lex Naturalis) hanya dalam karya Leviathan sahaja, tetapi juga dalam Elements of Law of Human Nature dan De Cive. Namun demikian Hobbes menjelaskan gagasan ini dengan cara yang berbeda. Dalam Elements of Law of Human Nature dan De Cive, Hobbes menempatkan Hukum Alam (Lex Naturalis) dan Hukum Tuhan (Lex Divintas) sebagai dua hal yang seiras. Dalam Leviathan hal ini tidak ditemukan. Dengan demikian, dapatlah diandaikan bahwa secara esensial, Hobbes menghubungkan antara gagasan Lex Naturalis dan Lex Divinitas (Hobbes, 1994). Jika Lex Naturalis sama dengan Lex Divinitas maka General Rule of Reason yang dimaksud Hobbes sama dengan Lex Divinitas.

Hubungan ini dapat dibuktikan melalui penjelasan Hobbes (1994) seperti berikut:

And first the word of God seemeth to place the divine law in reason: by all such text as ascribe the same to the heart and understanding; as Psalm 50.8: Thy Law is in my heart. Heb 8.10: After those days, saith the Lord, I will put my laws in their mind; and Heb10.16, the same. Psalm 37.31, speaking of the righteous man, he saith, The Law of God is in my heart. Psalm 19.7,8: The Law of God is perfect, converting the soul. It giveth wisdom to the simple, and light unto the eyes. Jer.31,33: I will put my law in their inward parts, and write in their hearts. And John 1, the lawgiver himself, God Almighty, is called by the name of 1 oyo $\zeta$, which is called: verse 4. The light of man and verse 9, the light which lighteth every man, which come into the world: all which are description of natural reason. 
Kutipan di atas menunjukkan bahwa Hobbes memahami: Divine Law (Hukum Tuhan) ditempatkan oleh Tuhan ke dalam akal dan hati tiap - tiap individu (R.J.Halliday, 1983). Karena itu secara alamiah, akal berfungsi memantulkan Hukum Tuhan. Hukum Tuhan yang dimaksud oleh Hobbes (Hobbes, 1947) adalah Firman Tuhan yang tertulis dalam Alkitab. Dalam karya-karya Hobbes, hukum yang dimaksud berbentuk Lex Naturalis yang di dalamnya termasuk juga first Fundamental Law of Nature: bahwa tiap tiap individu mencari perdamaian. Hobbes secara meyakinkan memberi argumentasi kokoh bahawa Lex Naturalis sama dengan Lex Divintas (Warrender, 1960). Dengan demikian, dapat dikatakan bahwa gagasan Hobbes dalam second Law of Nature, menyerahkan semua Hak-Hak Alamiah (Jus Naturalis) tiap-tiap individu untuk tujuan perdamaian publik, merupakan gagasan yang bersumber dari Lex Divinitas dan tidak mengingkari hukum akal. Implikasi dari penjelasan ini adalah, bahwa secara hirarki, Hukum Tuhan (Divine Law) adalah Hukum tertinggi diatas first Fundamental Law of Nature dan second Law of Nature.

\section{KEADAAN HIRARKI}

Jika penjelasan diatas menunjukkan bahwa demi perdamaian publik setiap individu patut menyerahkan semua hak-hak alamiahnya maka gagasan sosial kontrak harus dipahami sebagai bentuk paling tepat bagi penyerahan hak-hak alamiah itu. Oleh kerana Hukum Tuhan secara alamiah menjadi basis akal, maka sosial Kontrak harus dipahami sebagai buah dari proses akal individu-individu merealisasikan Hukum Tuhan, yaitu perdamaian (Thivet, 2008). Meskipun perdamaian dalam Hukum Tuhan itu menjadikan setiap individu kehilangan hak-haknya. Bagi Hobbes, Sosial Kontrak merupakan jalan satu satunya menciptakan perdamaian dan mengelakkan peperangan (Jaede, 2018). 
Gagasan penyerahan hak alamiah, oleh Hobbes direpresentasikan melalui beberapa terminologi, yaitu: pertama, to lay down a man' Right to anything, menunjukkan bahwa hak alamiah dapat diserahkan pada pihak lain. Kedua, simply renouncing. Menyerahkan hak alamiah dengan tidak memperhitungkan siapakah yang mendapat manfaat dari penyerahan hak itu. Ketiga, transferring, bermakna bahwa dari penyerahan hak alamiah itu, individu bermaksud mendapatkan manfaat dari seseorang atau beberapa orang yang ditetapkan. Implikasi pemindahan hak ini adalah, bahwa seorang individu tidak akan menghalang-halangi mereka yang dipercayai untuk memimpin (Hobbes, 1947).

Penyerahan Kekuasaan Alamiah (Transferring of Right) dapat dilakukan dengan dua cara yaitu: Contract dan Free Gift (Grace). Contract bermakna, pemindahan hak dari satu individu kepada individu yang lain dan sebaliknya (mutual transferring of right). Sedangkan Free Gift adalah penyerahan hak seorang individu kepada individu yang lain dengan maksud memperoleh manfaat seperti: persahabatan, reputasi atau pahala di sorga (Hobbes, 1947). Dalam kontrak, tiap-tiap individu diikat oleh Perjanjian (PACT atau COVENANT) untuk menjalankan kontrak. Kontrak melalui Pact atau Covenant ini hanya akan berjaya dijalankan jika masing-masing pihak setia memegang kepercayaan (Keeping Promise) (Trainor, 1985).

Perjanjian menyerahkan Hak Alamiah melalui Kontrak, memerlukan bukti atau tanda (signs). Hobbes mengusulkan dua bentuk tanda yaitu: Express dan Inference. Express, bermakna: perjanjian dilakukan secara literal, sedangkan Inference satu perjanjian yang tidak secara langsung dibuat tetapi sebagai konsekuensi dari undang-undang, tindakan, sikap diam atau tanpa pendapat (Hobbes, 1947). Dalam pembicaraan tentang perjanjian individu-individu mendapatkan perdamaian sebagai kesepakatan politik, Hobbes menggunakan terminologi Covenant. (Christov, 2015). Namun demikian Hobbes 
memahami bahwa perjanjian (Covenant) dengan kata-kata meskipun tertulis, tidak memiliki kekuatan untuk menciptakan perdamaian. Karena itu Hobbes memandang, harus ada Kekuatan Pedang untuk menghasilkan suasana aman (Hobbes, 1947). Kekuatan Pedang yang dimaksud Hobbes adalah satu kekuasaan tunggal yang dimiliki oleh satu orang atau sekelompok orang untuk mengelakkan konflik antara individu atau serangan dari luar. Kekuasaan tunggal tersebut berasal dari seluruh kekuatan dan kekuasaan yang dimiliki individu-individu. Dengan demikian, kekuasaan tunggal merupakan jumlah total kekuasaan dan kekuatan semua individu yang diserahkan di tangan penguasa. Kondisi ini oleh Hobbes dikatakan lebih dari perjanjian atau persetujuan. Ia menyebutnya dengan "real unity" Hobbes menegaskan tentang kekuasaan pedang sebagai kekuasaan tunggal, demikian:

This is more than consent, or Concord; it is a real Unitie of them all, in one and the same person, made by Covenant of every man with every man in such manner, as if every man should say to every man, I authorise and give up my Right of Governing myself, to this Man, or to this Assembly of man, on this condition in like manner. This done, the multitude so united in one Person, is called a COMMON WEALTH, in Latin CIVITAS. This is the Generation of that great LEVIATHAN, or rather (to speak more reverently) of that Mortal God, to which we owe under the Immortal God, our peace and defence.(Hobbes, 1947)

Kutipan di atas menunjukkan bahwa Hobbes mengawali gagasan tentang sosial kontrak bertumpu pada fakta adanya individu-individu yang independen yang menginginkan perlindungan, bukan satu komunitas atau kelompok masyarakat yang sedang memperjuangkan hak-hak mereka (Jaede, 2018). Gagasan masyarakat ada, pasca lahirnya kesadaran individu - individu tentang konflik atau perang. Pernyataan, I authorise and give up my Right of Governing myself, to this Man, or to this Assembly of man bermakna, bahwa tiap-tiap individu memiliki kesadaran yang sama bagi keharusan peranan pihak lain yang memiliki otoritas yang 
mampu mengelakkan konflik. Kesadaran ini, diteruskan dengan menyerahkan hak-hak individu kepada satu atau beberapa orang yang diberi hak untuk memerintah. Penyerahan hak ini, membawa implikasi hilangnya semua kekuasaan dan kebebasan yang dimiliki oleh tiap-tiap individu karena secara esensial, bagi Hobbes, hak alamiah merupakan hak untuk menggunakan kekuasaan dan kebebasan untuk kepentingan masing-masing individu. Tidak ada orang lain yang dapat mengganggunya. Namun gagasan penyerahan hak menjadikan semua individu dalam keadaan tanpa daya. Hal ini menjadi premis basis Hobbes tentang kekuasaan Leviathan atau Mortal God dalam satu Civitas (Negara). Bagi Hobbes, Civitas merupakan representasi dari semua individu didalamnya. Ia memiliki hak tunggal yang tidak dapat dilawan oleh sesiapa pun. Tidak ada kekuasaan lain yang dapat mengusiknya kecuali The Immortal God. Ini yang dimaksud oleh Hobbes dengan kekuatan Pedang (Evrigenis, 2014). Kekuasaan Negara atau state, oleh Hobbes dipandang sebagai subordinasi dari kekuasaan The Immortal God. Kekuasan Negara (Civitas) merupakan kekuasaan yang diterima oleh individu secara alamiah dari Tuhan yang kemudian dipindahkan kepada Negara melalui sosial kontrak.

Kekuasaan Negara dalam doktrin filsafat politik Hobbes adalah kekuasaan absolut. Ia bersumber dari tiap-tiap individu melalui Kontrak Sosial yang didasarkan kepada Perjanjian (Covenant) antara individu untuk menyerahkan hak-haknya kepada satu orang atau pada perhimpunan beberapa orang. Hobbes menjelaskan kekuasaan Negara itu demikian (Hobbes, 1947):

A Common-wealth is said to be Instituted, when a Multitude of men do Agree and Covenant, every one, with every one that to whatsoever Man, or Assembly of Men, shall be given by the major part, the Right to Present the Person of them all (that is to say, to be their representative;) every one as well he that Voted for it as he that Voted against it, shall Authorise all the Action and Judgement, of that Man, or Assembly of men in the same manner as if they were his own, to 
the end, to live peaceably amongst themselves, and be protected against other men.

Jelas, Hobbes memahami bahwa kekuasaan Negara adalah kekuasaan tunggal dan mutlak. Negara memiliki segala hak dan kekuasaan untuk mengatur hidup setiap individu, termasuk otoritas mutlak menghukum individu. Individu dalam satu Negara terikat dengan perjanjian yang ia buat. Ia tidak dapat membatalkan perjanjian, juga tidak dapat melawan kekuasaan Negara (Hobbes, 1947). Penjelasan ini menunjukkan demi keselamatan individu dan juga perdamaian, keadaan anarki harus ditinggalkan. Kekuasan hirarki adalah solusi bagi menciptakan perdamaian.

\section{KESIMPULAN}

Keadaan Alamiah (State of Nature) Thomas Hobbes dapat menjadi alasan bagi munculnya gagasan keaadan Anarki dan perang sebagaimana dibincangkan dalam Teori Realisme. Namun demikian dalam karya-karya Thomas Hobbes: Leviathan, De Cive, Human Nature and De Corpore Politico, ditemukan kontinuitas gagasan yang tidak dapat dibincangkan sepihak. Kontinuitas dimaksud adalah hadirnya Keadaan Alamiah (Anarki dan Perang) sebagai sumber rujukan Teori Realisme yang berakhir pada lahirnya Keadaan Hirarki (Kekuasaan Leviatan). Evolusi keadaan ini dibuktikan melalui rentetan gagasan koheren Hobbes yang dapat diformulasikan demikian: Bahwa manusia dalam keadaan alamiahnya, memiliki kekuasaan alamiah, hak alamiah, kesetaraan alamiah tanpa ada kekuasaan hirarki yang mengatur atau menghukum subyek jika terjadi konflik atau perang. Dalam keadaan Alamiah yang rawan konflik, Hobbes memahami ada rasio yang dapat menjadi sumber hukum mencegah perang. Namun rasio saja tidak cukup meskipun oleh kemampuan rasio dimaksud manusia sanggup menyadari bahwa keadaan damai menjadi kebutuhan substansial manusia. Keadaan damai dimaksud oleh Hobbes 
dapat tercapai jika ada kekuasaan Leviathan. Dengan munculnya kekuasaan Leviathan, Thomas Hobbes menunjukkan bahwa ada dua potensi dalam natur individu juga negara yaitu potensi perang dan juga damai. Sehubungan dengan Teori Realisme dapat dikemukakan bahwa rujukan pada Thomas Hobbes mengakibatkan teori Realisme Klasik dimaksud secara ideal menggambarkan hubungan Negara-Negara sebagai subjek berdasarkan dua natur di atas.

\section{DAFTAR PUSTAKA}

. (1947) Leviathan. Ernest Rys (ed). London: Morrsion \& Gibb.Ltd.

. (1994) Human Nature and De Corpore Politico. J.C.A Gaskin (ed). Oxford: Oxford University Press.

Bibio, N. (1993). Thomas Hobbes and The Natural Law Tradition. Chicago: University of Chicago Press.

Chong, A. (2005). Classical Realism and the Tension between Sovereignty and Intervention: Construction of Expediency from Machiavelli, Hobbes and Bodin. Journal of International Relations and Development, 257-286.

Christov, T. (2015). Before Anarchy: Hobbes and His Critics in Modern International Thought. New York: Cambridge University Press.

Evrigenis, I. (2014). Images of Anarchy: The Rhetoric and Science in Hobbes's State of Nature. New York: Cambridge University Press.

Gauthier, P David. (1969) The Logic of Leviathan.Oxford: Clarendon Press. Hobbes, Thomas. (1651) De Cive. John Roland (ed). London: R. Royston.

Jaede, M. (2018). Thomas Hobbes's Conception of Peace. Edinburgh: University of Edinburgh. 
Kavka, Gregory. (1983) Hobbe's War of All Against All. The University of Chicago Press: Ethics, 93:2.

Kinch, H. (2002). Hobbes on Law, Nature and Reason. Journal of The History of Philosophy, $111-120$.

Pedro, G. M. (2018). Reinhold Niebuhr and International Relation Theory: Realism Beyond Thomas Hobbes. New York: Routledge.

R.J.Halliday, T. K. (1983). Hobbes's Belief in God. Political Studies, 418433.

Skinner, Q. (1996). Reason and Rhetoric in the Philosophy of Hobbes. Cambridge: Cambridge University Press.

Stephen McGlinchey, R. W. (2017). International Relations Theory. Bristol: E-International Relations Publishing.

Strauss, Leo. (1963). The Political Philosophy of Hobbes.Chicago: The University of Chicago Press.

Thivet, D. (2008). Thomas Hobbes: A Philosopher of War or Peace? British Journal for the History of Philosophy, $701-721$.

Trainor, B. T. (1985). The Politics of Peace: The Role of the Political Covenant in Hobbes's Leviathan. The Review of Politics, 347-369.

Warrender, H. (1960). The Place of God in Hobbes's Philosophy. Political Studies, 48-57. 